\title{
APORTES CONCEITUAIS E TECNOLÓGICOS DA AGRICULTURA ORGÂNICA PARA A OLERICULTURA NA COMUNIDADE BURITI - ASSENTAMENTO TARUMÃ-MIRIM (MANAUS, AM)
}

\section{CONCEPTUAL AND TECHNOLOGICAL CONTRIBUTIONS OF ORGANIC AGRICULTURE FOR VEGETABLE CROPS IN COMMUNITY BURITI - TARUMÃ- MIRIM NESTING (MANAUS, AM)}

\section{Marinice Oliveira Cardoso ${ }^{1}$; Joanne Régis da $\operatorname{Costa}^{1}$; Isaac Cohen Antonio ${ }^{1}$}

${ }^{1}$ Pesquisadores da Embrapa Amazônia Ocidental, C. Postal 319, 69010-970 Manaus-

AM; marinice.cardoso@embrapa.br; joanne.regis@embrapa.br isaac.cohen@embrapa.br;

\section{Resumo}

Neste relato descrevem-se ações visando aportes conceituais e tecnológicos da agricultura orgânica para a olericultura familiar da Comunidade Buriti - Assentamento TarumãMirim (Manaus, AM), por meio de uma Unidade Central Modelo (UCM). O procedimento constou de palestras, curso e reuniões, além da instalação e condução da UCM, nos moldes de Unidade de Observação, para validar resultados de pesquisa sobre o manejo orgânico de hortaliças. A UCM constituiu-se numa referência eficaz em termos de transferência de tecnologia, em face da adoção do manejo do solo e do uso de biofertilizante nos modestos sistemas de cultivo dos integrantes. A produção protegida foi assimilada com irrigação manual substituindo o gotejamento, configurando adaptação circunstancial por restrição financeira. Portanto, a validação tecnológica se deu com aspectos que se modificaram circunstancialmente, contudo, sem dissociação das características dos recursos tecnológicos. No contexto geral, o grupo denotou domínio relativo dos conceitos e das práticas aplicados. 
Palavras-chave: transferência de tecnologias, agricultura familiar, biofertilizante, manejo orgânico.

\begin{abstract}
In this report are described actions to conceptual and technological contributions of organic agriculture for family vegetables crops in Community Buriti - Tarumã-Mirim nesting (Manaus, AM), through a Central Unit Model (UCM). The procedure consisted of lectures, course and meetings, in addition to installation and driving the UCM, which was an Observation Unit to certify the results of research on the organic cultivation of vegetables. The UCM constituted an effective benchmark in terms of technology transfer, due to the adoption of soil management and use of bio fertilizers in modest farming systems of the members. The protected production had adoption with manual irrigation replacing the drip setting, circumstantial adaptation by financial constraint. Therefore, the technology validation take place with aspects that have changed circumstantially, however, without dissociation of the characteristics of technological resources. In the general context, the group denoted domain on concepts and applied practices.
\end{abstract}

Key words: technology transfer, family farming, biofertilizer, organic management.

\title{
1. Introdução
}

O Estado do Amazonas (1.559.161,682 $\mathrm{km}^{2}$ ) possui 3.480.937 habitantes, com a capital Manaus respondendo por 51,8\% desse total populacional (IBGE, 2011). O maior consumo de hortaliças é atribuído à aglomeração formada pela Região Metropolitana de Manaus (RMM), representada pela extensão da capital amazonense com seus municípios vizinhos. Na RMM sobressai a atividade de produção de olerícolas por agricultores familiares. Esses agricultores se caracterizam por exercerem a direção dos trabalhos no estabelecimento, com mão de obra familiar superior à contratada (Guanziroli et al., 2001), renda familiar originada predominantemente das atividades econômicas do estabelecimento e propriedades com área de até quatro módulos fiscais (Lei $n^{0} 11.326$, de 24 de julho de 2006).

As hortaliças, por serem lavouras temporárias, de rápido retorno de capital e com garantia de mercado no Estado, constituem alternativa para melhoria sócioeconômica desse público de agricultores, especialmente por meio da agricultura orgânica (AO). A produção orgânica é considerada boa perspectiva aos pequenos agricultores, pelos menores custos efetivos, maiores relações benefício-custo e maiores rendas líquidas, além de atender a um 
segmento restrito e seleto de consumidores, que pagam um sobrepreço pelos produtos, desse modo, mesmo não atingindo grande escala produtiva, os produtores podem disponibilizar seus produtos em pequenos mercados locais (Campanhola \& Valarini, 2001). Outro aspecto, diz respeito à oferta de produtos especializados que não despertam interesse dos grandes empreendedores agropecuários, como as hortaliças e as plantas medicinais, que historicamente são produzidos, sobretudo, por pequenos agricultores, além da tão conhecida diversificação da produção, que confere ao pequeno agricultor a vantagem da estabilidade da renda durante o ano (Castro Neto et al., 2010).

Entretanto, um sistema orgânico de produção não é obtido somente com a troca de insumos químicos por insumos orgânicos/biológicos/ecológicos, requerendo comprometimento com o sentido holístico da produção agrícola. Nesse sentido, é condição básica que os agricultores sejam capacitados quanto aos princípios da $\mathrm{AO}$, aos objetivos da visão da propriedade como um organismo, à integração da agricultura e da pecuária para fertilização do solo, à importância da biodiversidade, às práticas ecológicas de conservação e todos os outros conhecimentos para cultivar com eficiência técnica e econômica (Mazzoleni \& Nogueira, 2006). Por outro lado, Oliveira et al. (2008) destacam que além de investimentos sociais e estruturantes, a agricultura familiar necessita de tecnologias apropriadas, assim como, enfatizam a necessidade de que as intervenções respeitem a cultura e os costumes locais das comunidades.

\section{Objetivo}

As normas e procedimentos técnicos da agricultura orgânica, por estarem bem estabelecidos, além de ser um modelo de produção bastante difundido entre os agricultores, proporcionam condições teóricas e práticas para ações visando graus maiores de sustentabilidade dos sistemas de cultivo, independente da certificação. Isso porque, a transição agroecológica interna ao sistema produtivo agropecuário passa por diversas etapas. Também, os consumidores não se preocupam com as diferenças entre os tipos de agricultura alternativa abordados, considerando todos os seus produtos simplesmente como produtos orgânicos, pois a sua principal preocupação é com o consumo de alimentos sem agrotóxicos e sem outras substâncias químicas sintéticas prejudiciais à saúde (Campanhola \& Valarini, 2001). Desse modo, o presente trabalho objetivou efetuar aportes conceituais e tecnológicos da agricultura orgânica para a produção de hortaliças por agricultores familiares da Comunidade Buriti, no 
Assentamento Tarumã-Mirim, município de Manaus - AM, por meio de uma Unidade Central Modelo (UCM), com significado conceitual de Unidade de Observação (UO).

\section{Antecedentes}

Assentamento Tarumã-Mirim - O Assentamento Tarumã-Mirim, criado pelo INCRA (Instituto Nacional de Colonização e Reforma Agrária), ocupou áreas (42.910,76 ha) da União na Zona Rural do Município de Manaus (Resolução 184/92 de 20/03/1992), tendo capacidade para assentar 1.042 famílias (INCRA, 1999), intencionado a integração ao processo produtivo da região (Matos et al., 2009). Esse Projeto de Assentamento, na região oeste do município de Manaus, está situado em quase sua totalidade dentro da Área de Proteção Ambiental (APA) Margem Esquerda do Rio Negro, Setor Tarumã-Açu/ Tarumã-Mirim (Lei n. ${ }^{\circ}$ 6.902, de 27 de abril de 1981), criada com o "interesse na proteção ambiental", sem proibição explícita aos loteamentos, mas contendo restrições quanto à alteração das condições ecológicas locais" (Nascimento, 2009). Contudo, dados da Universidade Federal do Amazonas (UFAM) revelaram uma intensificação do desflorestamento na área, entre 1990 e 2009, sendo atribuída ao citado Projeto, que ocupa $83 \%$ da área da APA, a responsabilidade por $78 \%$ de todo o desflorestamento ocorrido na Unidade de Conservação até o ano de 2009 (Nascimento \& Silva, 2010). A retirada da cobertura vegetal relacionava-se com atividades como a produção de carvão vegetal e lenha, exploração de madeira e prática da agropecuária.

Comunidade Buriti - A Comunidade Buriti, parte desse Assentamento, tinha como atividade principal a produção de carvão, sem licenciamento ambiental, para abastecer o mercado ilegal em Manaus, antes da conversão produtiva para a produção de hortaliças. Pelo menos duas toneladas do produto eram retiradas semanalmente, com reflexos sobre o ambiente e a qualidade de vida dos agricultores, devido ao poder depredador e a nocividade da atividade carvoeira à saúde. A conversão produtiva, por ações da Embrapa Amazônia Ocidental, em parceria com o Ifam (Instituto Federal de Educação, Ciência e Tecnologia do Amazonas) era de grande interesse da Comunidade devido à insalubridade da atividade carvoeira, à necessidade de atendimento da legislação ambiental diante da pressão dos órgãos ambientais, à possibilidade de geração de renda e particularmente, para autoconsumo. Assim, em 2011, constatou-se aumento de $28 \%$ na renda semanal com a venda direta de hortaliças pelos seus olericultores, com média de 1,65 pessoas por família envolvidas na olericultura, desse modo, havendo redução significativa do desmatamento de floresta/ capoeira por ano (Costa \& Soares, 
2013). Nessa comunidade é notória a rejeição pelas práticas agroquímicas do cultivo convencional.

\section{Metodologia}

\section{Base teórica}

A metodologia constou de uma "Unidade Central Modelo" (UCM), conduzida de forma coletiva como referência para as famílias envolvidas, com adaptação do sistema "Modelo Regeneração de Agricultura Familiar” (Oliveira et al., 2008). A UCM incorporava o conceito de Unidade de Observação (UO), que é o instrumento utilizado para observação/validação de resultados gerados ou de interesse, em diferentes ambientes e épocas, antes da obtenção do resultado final, podendo a instalação ser feita isoladamente ou em parceria com outras organizações, em área da própria unidade de pesquisa ou de terceiros, podendo ser com a colaboração de produtores, cooperativas, instituições de pesquisa pública ou privada (Embrapa, 2009). Por outro lado, na extensão rural, é um recurso metodológico planejado, montado e desenvolvido pelos extensionistas rurais e o produtor rural (colaborador), com o qual observará o comportamento de uma ou mais práticas agronômicas ainda desconhecidas, na prática, naquela região, e julgadas de interesse sócio-econômico, porém, que terão um parecer técnico definitivo emitido após a obtenção dos resultados da UO (Emater, 2009). Segundo Franco (2002), UO é um procedimento da transferência de tecnologia que objetiva testar em condições reais de produção a aplicabilidade de uma ou mais práticas agropecuárias não utilizadas pelos produtores e nem amparadas pela pesquisa na região. Aqui, o produtor rural foi representado pelo coletivo das famílias envolvidas, e as ações foram conduzidas de modo que os integrantes do grupo fossem parte atuante. Na busca cooperada de conhecimentos a participação é condição fundamental, assim, agricultores familiares não seriam objeto de pesquisa, mas sujeitos da pesquisa (Noda et al., 2009). Portanto, procurou-se empoderar os integrantes para suas análises, com domínio decisivo, no processo de validação e de transferência tecnológica relacionado à proposição de aportes de recursos tecnológicos.

\section{Planejamento prévio}

O processo geral das ações na Comunidade Buriti se deu pela execução de planejamento prévio, em etapas, com desenvolvimento das seguintes atividades: a - Palestra preliminar; $b$ Palestra de apresentação do projeto base; c - Curso “Temas e práticas sobre agricultura orgânica 
adaptadas às condições da Comunidade Buriti - Tarumã Mirim"; d - Instalação e condução da UCM/UO, além de avaliações pertinentes.

\section{Atividades principais - execução e contexto}

\subsection{Palestra preliminar}

Palestra sobre a "produção convencional e orgânica de hortaliças" (Figura 1a), para a qual toda a comunidade foi convidada. No decorrer, ficou manifesto que os agricultores tinham preferência pela "produção orgânica", em face de discernimento, anteriormente adquirido, sobre os sistemas. Entretanto, era um conceito que seria melhor definido como "produção sem agrotóxicos", captando-se o seguinte: a comunidade tem preferência pela produção orgânica, porém, a abordagem correta do sistema não é devidamente conhecida. Esta palestra foi remota ao início das atividades, denotando aproximação anterior entre a equipe técnica e os comunitários.

\subsection{Palestra de apresentação do projeto base}

Num segundo momento, houve uma palestra para apresentação, pela equipe, do projeto base para as ações ("Biofertilização em cultivo solteiro e consorciado de hortaliças sob manejo orgânico em condições de terra firme no Estado do Amazonas", da Embrapa Amazônia Ocidental) e dos seus resultados com hortaliças utilizando manejo orgânico em ambiente protegido na terra firme, ou seja, o mesmo ecossistema da comunidade (Figura 1b). O diálogo com os comunitários sobre os itens apresentados foi intenso, assim como, sobre a possibilidade de um trabalho na Comunidade, por meio da instalação de uma UCM. Após o encerramento da palestra, nove famílias manifestaram interesse em participar do mencionado trabalho, representadas por oito mulheres e um homem. A participação majoritária feminina nessa comunidade já foi descrita por Costa \& Soares (2013). Também foram feitas discussões a respeito do local de instalação da UCM, por diante, UO.

Por consenso, foi escolhida a propriedade de uma das agricultoras (D. Guiomar Batista) para ser implantada a UO com uso de práticas da agricultura orgânica para hortaliças (Figura 2). A propriedade tem fácil acesso a todos do grupo envolvido, para onde os participantes seguiram visando escolha da área específica destinada à UO. A área foi escolhida em discussão entre técnicos e comunitários, considerando os seguintes critérios: área plana, com água disponível, acesso fácil, sem tocos de árvores (para facilitar a limpeza da área). Logo, realizou- 
se a coleta de solo na área para análise no Laboratório de Solos e Plantas da Embrapa Amazônia Ocidental. No período de condução da UO (agosto a novembro de 2014), os dados agrometeorológicos registrados na Estação Agrometeorológica da Embrapa Amazônia Ocidental foram: média da temperatura do $\operatorname{ar}=26,7^{\circ} \mathrm{C}$ e da umidade relativa $=85,35 \%$; e, precipitação pluviométrica total de $698,6 \mathrm{~mm}$.

5.3. Curso "Temas e práticas sobre agricultura orgânica adaptadas às condições da Comunidade Buriti - Tarumã Mirim”

Antes da instalação da UO foi realizado um curso para os envolvidos, aberto aos demais comunitários, desse modo, iniciando os aportes conceituais. O curso constou basicamente sobre práticas da agricultura orgânica passíveis de serem realizadas frente às condições agrossocioeconômicas da Comunidade (Figura 3), sempre em coerência com os resultados obtidos no projeto base para as ações, antes mencionado. Além de alguns recursos tecnológicos da olericultura considerados mais avançados (Alves et al., 2006: "se o agricultor deixar de escolher a tecnologia lucrativa é porque a desconhece ou porque enfrenta restrições que não pode contornar"). Assim como, sobre a garantia da qualidade dos produtos orgânicos no Brasil (a - certificação por certificadoras; b - sistema participativo de garantia - spg; e c - controle social para venda direta sem certificação ou seja, entre o produtor e o consumidor final, sem intermediários).

Assim, o programa do curso constou de "Noções de certificação" - "Experiências associativistas exitosas com agricultura orgânica e sustentabilidade" - "Manejo do solo com fertilizantes orgânicos sólidos e biofertilizante no suprimento de macronutrientes e micronutrientes" - "Práticas de calagem, de uso de fosfato natural e de adubos orgânicos sólidos" - "Preparo de diferentes biofertilizantes" - "Método de irrigação e adaptações (bomba e gravidade) em cultivo protegido" - "Montagem do sistema de irrigação, com ênfase em gotejamento". Aos participantes foi fornecido o material didático sobre os temas abordados. Particularmente, deu-se amplo enfoque aos produtos naturais ou de preparo caseiro, para o controle de insetos pragas e doenças (Amaro et al., 2007).

\subsection{Instalação e condução da $U O$}

A UO teve a instalação efetuada em etapas, com os envolvidos realizando, principalmente, as atividades laborais com suas próprias ferramentas, acompanhados pela 
equipe técnica, que semanalmente efetuava as visitas técnicas. As rodas de conversas foram momentos estratégicos para o êxito da condução da UO. Os materiais requeridos e os serviços foram disponibilizados, conforme os haveres da equipe/projeto e dos comunitários envolvidos, respectivamente. Desse modo, os recursos financeiros do projeto proveram os materiais necessários e os participantes deram a contrapartida em atividades laborais, entre outros (ex: madeira da estrutura do cultivo protegido, serrada no próprio local; sistema de captação de água do igarapé, bancada de produção de mudas, etc). Em cada etapa do trabalho, os participantes recebiam a descrição das práticas e das recomendações técnicas impressas, que eram por eles colecionadas. Todas as práticas de manejo utilizadas foram adaptadas, nas ações do projeto base, para atender as normas da produção orgânica nas condições regionais. Ressalta-se, que as mulheres tiveram um papel fundamental, participando ativamente e contribuindo decisivamente para a implementação das atividades em geral (Figura 4).

Estrutura para cultivo protegido - Inicialmente, foi construída a cobertura com filme plástico transparente, com a madeira provida pela Comunidade, enquanto, pelo projeto, a equipe providenciou o filme plástico apropriado (concluída: 28/07/14). A área da estrutura foi de $108 \mathrm{~m}^{2}$ (18 m de comprimento $x 6 \mathrm{~m}$ de largura). Regionalmente, a produção em cultivo protegido é praticado como efeito guarda-chuva, devido aos elevados índices de precipitação pluviométrica em determinado período do ano, período chuvoso, tendo sido proposto na Comunidade Buriti, tendo em vista que, nessa comunidade, o período chuvoso é a melhor época de cultivo, em face dos problemas relacionados com a disponibilidade de água, desse modo, a água da chuva é coletada para irrigar as hortaliças.

Na dimensão do comprimento, em metade da cobertura, colocou-se tela sombrite preta associado com o plástico transparente (Figura 5), visando atestar o efeito do sombrite quanto ao conforto térmico, particularmente para a alface. Além disso, essa tela é bastante utilizada na Comunidade. Deu-se ênfase, para a obrigatoriedade da reciclagem do plástico e do sombrite, ou materiais dessa natureza.

Preparo dos canteiros e calagem - Os canteiros foram confeccionados, nos moldes conhecidos pelos agricultores (Figura 6a), desse modo, valorizando os saber local. Entretanto, discutiu-se com os comunitários, que o espaço sob a cobertura pelo seu elevado valor monetário agregado (comparado à céu aberto), deve ser bem aproveitada com as culturas, tendo em vista a demasiada folga entre os canteiros. Na sequência, foi realizada a calagem nos canteiros (em 
toda sua extensão), com base na análise do solo, que indicou características de solo álico distrófico (12/08/14). Desse modo, utilizou-se o método que leva em consideração a saturação de Al no complexo de troca de solos minerais ácidos (nível de saturação desejada para hortaliças $=5 \%$ ), aguardando-se a reação do corretivo com o solo. O solo possuía acidez elevada, teores médios de matéria orgânica, teores de $\mathrm{P}$ e $\mathrm{K}$ muito baixos, com $\mathrm{V}(\%)=8,64$ e índice de saturação de $\mathrm{Al}(\%)$ = 69,30; além de teor alto de $\mathrm{Fe}$ e baixos de $\mathrm{Zn}, \mathrm{Cu}$ e $\mathrm{Mn}$. O calcário apresentava valor elevado do PRNT (91\%), $\operatorname{com~} \mathrm{CaO}=32 \%$ e $\mathrm{MgO}=15 \%$, características que favorecem à rápida reação com o solo.

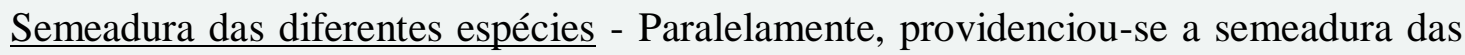
espécies (18/08/14: alface, couve, cebolinha, pepino, pimentão e tomate), em bandejas de poliestireno expandido (Figura 6b), exceto o coentro. As espécies listadas são muito demandadas no mercado regional. Próximo ao plantio, efetuaram-se a aplicação do fosfato natural reativo Arad (em toda extensão dos canteiros, 1,0 t ha ${ }^{-1}$ ) e esterco de galinha, conforme cada espécie e a análise do solo, com explicações simples e práticas sobre os cálculos e os procedimentos. As quantidades dos insumos eram quantificados (litro ou gramas por planta ou área do canteiro), sendo confeccionadas as "medidas" para facilitar a execução das tarefas. A semeadura de diferentes espécies foi para atender à diversificação, peculiar na agricultura familiar.

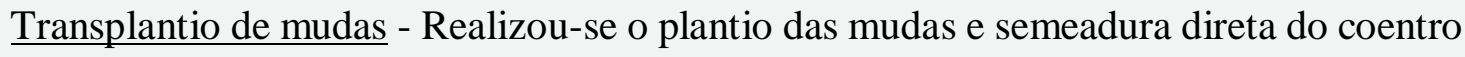
(08/09/14), adotando-se os seguintes espaçamentos: hortaliças-de-folhas: alface Lucy Brown; Soláris e Regina - 25 cm x 20 cm; couve-de-folhas (Hy crop) - $90 \mathrm{~cm}$ x $50 \mathrm{~cm}$; cebolinha (híbrido Hossunegui) - $25 \mathrm{~cm}$ x $20 \mathrm{~cm}$; coentro (Verdão) $-25 \mathrm{~cm}$ x $10 \mathrm{~cm}$ (fileiras duplas) x 5 cm (entre plantas); hortaliças-de-frutos: tomate (Belém - 70), pimentão (Yolo wonder), pepino (Aodai) e quiabo (hibrido Dardo) $-100 \mathrm{~cm}$ x $50 \mathrm{~cm}$.

Sistema de irrigação - Antes do transplantio das mudas de cada cultura, entretanto, foram instaladas as fitas gotejadoras do sistema de irrigação por gotejamento (Figura 6c), que teve suas outras partes componentes instaladas previamente (cabeçal de controle, linha principal e linhas de derivação de distribuição de água). O uso desse sistema de irrigação visou assegurar o fornecimento de água às plantas e, igualmente, acrescentar conhecimentos sobre essa tecnologia aos agricultores envolvidos com a UO, pois o gotejamento vem aumentando em áreas específicas na agricultura brasileira, particularmente com hortaliças. 
Preparo do biofertilizante - Foi programado, de modo que estivesse acabado, para uso em cobertura, na época requerida pelas espécies (início do preparo:14/08/14), tendo o processo sido acompanhado com grande interesse por todos. Isso porquê, o uso do biofertilizante teve, além do enfoque técnico, o fato de ser o principal foco dos resultados do projeto base. Os participantes possuíam experiência anterior sobre o preparo desse insumo com resíduos de alimentos e/ou produtos vegetais, que consideravam "fraco", portanto, se interessaram pelo preparo do biofertilizante de esterco bovino enriquecido com nutrientes admitidos na agricultura orgânica. À primeira aplicação do biofertilizante (14/09/14), seguiram-se outras, semanalmente. As aplicações foram sempre no solo, sendo discutidas com os envolvidos, que o uso no solo representa opção mais segura, particularmente para hortaliças folhosas, sob a égide das Boas Práticas Agrícolas (BPA).

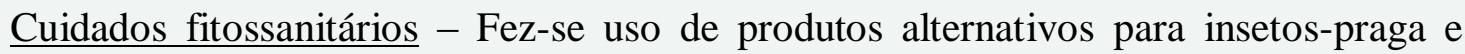
doenças. Nos cultivos em geral, utilizou-se extrato de nim, particularmente nas bandejas de mudas, para repelir insetos cortadores. E de calda bordalesa, em doença fúngica foliar, no pepino.

Colheita e avaliações - Após cada colheita (hortaliças folhosas - 08/10/14; hortaliçasde-frutos - 10/11/14), os participantes providenciavam o destino da produção, em geral, para autoconsumo ou venda direta, por meio das feiras de agricultores familiares (Ex: Feira do ramal da Cooperativa, próximo da Comunidade e Feira da Sepror - Parque Expoagro, na zona urbana de Manaus). O desempenho das diferentes espécies era frequentemente discutido por ocasião das visitas.

Encerramento das atividades e confraternização - No encerramento das atividades efetuou-se a avaliação do trabalho e confraternização (Figura 7), que se deu aos 120 dias após a conclusão da cobertura com filme plástico (24/11/14). A avaliação objetivou sondar a satisfação e o provável emprego futuro das práticas. Para tanto, foram abordados itens como "a cultura de melhor desempenho", "o cultivo que poderia ser reproduzido com certeza", "manejo dos insumos orgânicos e químicos no solo", "os aspectos do uso do sombrite" e "o biofertilizante como um recurso viável na comunidade". Assim como, sobre os sistemas de irrigação e em cultivo protegido.

\section{Resultados e impactos alcançados}




\subsection{Resultados parciais}

\subsubsection{Desempenho agronômico das espécies cultivadas}

O desempenho agronômico das espécies adquire importância porque evidencia o êxito das práticas utilizadas em cada um dos sistemas de cultivo das espécies. Desse modo, são apresentados aspectos do desempenho das culturas (Figura 8):

Alface - considerando o canteiro de $7 \mathrm{~m}$ (1m de largura), em cada cultivar, e um período médio de 30 dias, a cv. Regina (lisa) produziu 82 cabeças e um total de 1886 folhas; a cv. Solaris (crespa), 82 cabeças e o total de 1148 folhas; enquanto a cv. tipo americana (Lucy Brown) produziu 82 cabeças e número de folhas total de 1148. Em vista da ausência de balança no local, somente algumas cabeças foram pesadas (Embrapa CPAA), apresentando peso médio de 200 g. Na feira foram comercializadas a $R \$ 2,00$ por cabeça/pé, com renda bruta de $R \$ 416,00$. As cabeças produzidas chamaram a atenção pelo excelente desenvolvimento, tendo em vista que nas condições regionais as temperaturas elevadas são prejudiciais à alface, mesmo para as cultivares de verão, pois é notório que temperaturas elevadas favorecem a emissão do pendão floral com interrupção da fase vegetativa. Para as três cultivares, as plantas sob o sombrite tiveram melhor desempenho, seguramente pelo conforto térmico proporcionado por esse tipo de tela, sob a cobertura com plástico transparente, aliado à provável maior retenção de umidade no solo.

Coentro ( $4 \mathrm{~m}$ de canteiro de $1 \mathrm{~m}$, associado com cebolinha) - foram obtidos 7,74 maços de 500 g (1 maço, aproximadamente $\mathrm{R} \$ 5,00)$. Essa espécie teve visível prejuízo no desempenho sob o sombrite, denotando que a redução da luminosidade afetou-a negativamente, o que é importante porque o sombrite é, em geral, utilizado na Comunidade, particularmente com essa espécie. Mesmo considerando esse rendimento, caso fosse utilizada toda a área útil sob a cobertura $\left(90 \mathrm{~m}^{2}\right)$, a produção poderia atingir $78750 \mathrm{~g}$ (1575 maços; aproximadamente, $01 \mathrm{~kg}$ por $\mathrm{m}^{2}$ ). Nas condições regionais, o coentro é um condimento muito demandado, em certos casos sendo produzido sob cultivo protegido, com ótima rentabilidade.

Cebolinha - a produção das touceiras de plantas (224) não foi estimada, pois os participantes optaram por deixar o material para divisão com vistas a propagação vegetativa. Considerando cada touceira com 4 plantas (224 x $4=896$ plantas) e cada planta produzindo duas folhas, semanalmente, seriam 1792 folhas em cada semana. A cebolinha é propagada a 
partir de sementes ou vegetativamente, por divisão dos pés. Assim, as plantas obtidas a partir da semeadura em bandejas não foram colhidas por desejo dos participantes. Isso é coerente com interesse para estabelecimento de novo cultivo, ou mesmo, autoconsumo.

Tomate (cv. Belém 70, de crescimento determinado, com tolerância à murcha bacteriana) - as 18 plantas, com produção de $400 \mathrm{~g}$ de frutos por planta, que, de início, foi destinada à obtenção de sementes (por não ser cv comercial e não há sementes no mercado). Os primeiros frutos foram doados à equipe técnica, para retirada de sementes e uso futuro, sendo o restante consumido na Comunidade. Regionalmente, o tomate é cultura de risco, por ser espécie sobremaneira sujeita a problemas fitossanitários, sendo o controle fitossanitário uma tarefa de grande complexidade. Entretanto, o desempenho da cultivar utilizada permite boa produção visando o autoconsumo e mercados locais, porém, exige um manejo mais intensivo, quando pode atingir $57 \mathrm{t} \mathrm{ha}^{-1}$. Contudo, essa solanácea não despertou entusiasmo do grupo envolvido, por sua maior exploração comercial. O tomate comercializado na cidade e arredores de Manaus é quase todo importado de outras regiões (São Paulo e Minas Gerais), exigindo certa competitividade. Os riscos inerentes da cultura não estimulam os agricultores.

Quiabo - considerando a produção de 20 frutos/planta, até o encerramento, estimou-se total de 360 frutos/18 plantas $(6,12 \mathrm{~kg}$, com peso de fruto de $17 \mathrm{~g})$. Entretanto, as plantas continuaram em produção. O preço do quiabo, em 2014 , foi de $\mathrm{R} \$ 0,50$ à $\mathrm{R} \$ 4,00$ por $\mathrm{kg}$. $\mathrm{O}$ quiabo Dardo, nas condições regionais, em solo com ótimos níveis de fertilidade, produziu com uso de uréia (em cobertura) 36 frutos por planta e 31 frutos por planta, com uso de esterco de galinha (Cardoso \& Berni, 2012), portanto, a produção parcial de 20 frutos por planta pode ser considerada adequada, tendo em vista que aqui foi até os 60 dias em média, enquanto no exemplo, o período produtivo foi de 105 dias. Caso fosse utilizada toda a área útil de cultivo protegido $\left(90 \mathrm{~m}^{2}\right)$ com essa espécie, ter-se-ia o total de 180 plantas, que produziriam em 105 dias, aproximadamente, $95 \mathrm{~kg}$. A renda com essa cultura pode ser incrementada, caso seja adotado a consorciação, no início do ciclo, com outra espécie que agregue valor, como o coentro.

Pimentão - As plantas remanescentes (24 plantas) produziram aproximadamente $15 \mathrm{~kg}$ de frutos (o preço é de $\mathrm{R} \$ 6,00$ reais o $\mathrm{kg}$, do produto híbrido), no caso sendo "yolo wonder" uma variedade, estimou-se venda, na feira a $\mathrm{R} \$ 3,00 / \mathrm{kg}$. Supondo o uso de toda a área útil em cultivo protegido com essa espécie, ou seja $90 \mathrm{~m}^{2}$, ter-se-ia o total de 180 plantas de pimentão 
com produção de $113 \mathrm{~kg}$ (x R $\$ 3,00=\mathrm{R} \$ 339,00)$, em período de 60 dias, entretanto o ciclo pode se alongar à mediada dos tratos culturais (150 dias). Essa espécie é muito explorada em cultivo protegido na região de Manaus, com práticas convencionais. Por meio da produção alternativa, o produto pode ter maior remuneração.

O pepino foi severamente atacado por queima-das-folhas, sendo a produção muito prejudicada (média de dois frutos/planta). Esse problema ensejou a prática de preparo e uso da calda bordalesa. A couve-de-folhas sofreu severo ataque de formigas cortadeiras, que prejudicou o estande. As formigas cortadeiras constituem um problema frequente nessa Comunidade.

\subsubsection{As perspectivas dos agricultores, no encerramento}

Sobre a satisfação e o provável emprego futuro das práticas, os participantes afirmaram que poderiam reproduzir o cultivo de todas as espécies, da forma aplicada na UO. Portanto, isso confirma que o cultivo diversificado de hortaliças folhosas e de frutos sob manejo orgânico com uso de biofertilizante, como prática agronômica, foi de modo geral exitoso. O uso do biofertilizante como prática agronômica constituiu o principal foco do projeto base para as ações. Todos apontaram a alface (três tipos: lisa, crespa e americana) como a espécie que se destacou, havendo grande ênfase quanto a alface americana.

Os participantes citaram que o uso do sombrite, nas condições agroclimatológicas do período da UO, afetou positivamente a performance das alfaces, o que foi associado com maior conforto térmico em relação à cobertura somente com filme plástico. $\mathrm{O}$ uso do calcário e do fosfato natural, admitidos na agricultura orgânica, foram corretamente associados com a necessidade de correção do solo e de fornecer ao solo os nutrientes faltantes ( $\mathrm{Ca}, \mathrm{Mg}$ e $\mathrm{P})$, conforme a ênfase quanto à análise do solo durante o processo. Isso porque, tinham como problemático, particularmente, o cultivo de hortaliças de frutos em face do solo distrófico. Reconheceram ainda o esterco e o biofertilizante enriquecido como dois produtos orgânicos importantes para uso no solo, visando a boa produção das culturas. Mencionaram as cinzas obtidas do forno de farinha de mandioca como fonte de potássio no biofertilizante, além das fontes de micronutrientes permitidas que foram adicionadas. De modo geral, esses foram os pontos de grande valor das atividades práticas, que atestaram o domínio relativo de conhecimentos e das práticas aplicadas. 


\section{- Inferências parciais:}

Com o desempenho agronômico satisfatório das espécies cultivadas e as evidências sobre a percepção positiva do grupo, no encerramento e avaliação da UCM, seria possível inferir que o objetivo proposto, de efetuar aportes conceituais e de recursos tecnológicos da agricultura orgânica para a produção de hortaliças na Comunidade Buriti fora alcançado.

Sobre os aportes conceituais, a prática extensionista fundamentada no construtivismo piagetiano terá como um ponto de partida os conhecimentos prévios já construídos no processo histórico social e como ponto de chegada os conhecimentos ressignificados pelos atores no processo de aprendizagem (agricultores e técnicos), onde o ponto de chegada se constitui sempre num saber prévio para o próximo desafio, além de que muitas informações podem ser descartadas porque são incompatíveis com os saberes prévios (Emater, 2009). Portanto, os aportes conceituais são intangíveis sem avaliações formais, que não são adequadas com os agricultores.

Por outro lado, como se utilizou uma Unidade Central Modelo (UCM), onde foram testadas recursos tecnológicos quanto à sua adequação às condições dos agricultores ou visando ampliar os seus conhecimentos, os resultados satisfatórios per si associados à expectativa animadora dos integrantes não atestam a sua adoção e reprodução. Embora considerando que o termo validação tecnológica é usado para designar as avaliações de tecnologia em nível de propriedade ou para definir as atividades de pesquisa nas quais os usuários estejam envolvidos na identificação do problema, na definição das opções, na condução da unidade de teste e validação e no processo de avaliação dos resultados (Melo 2008), entretanto, as inferências conclusivas devem ser feitas com prudência.

\subsection{Resultados finais e impactos}

O acompanhamento realizado após o encerramento das atividades na Comunidade (após 15 meses), permitiu avaliar o efeito de referência da UCM/UO sobre o sistema de cultivo de cada um dos integrantes:

Cultivo protegido e Irrigação por gotejamento - Com exceção de um dos participantes, os demais construíram estruturas de cultivo protegido, com dimensões aproximadamente iguais (10 m x $5 \mathrm{~m}$ ), aproveitando materiais residuais do projeto. Ressalta-se que não se estabeleceu comprometimento específico sobre a destinação desses materiais de consumo remanescentes. 
A estrutura de cultivo protegido da UO, que permaneceu no local, por decisão dos integrantes, continuou sendo utilizada por D. Guiomar e sua filha (Figura 9). Entretanto, com os demais, alguns problemas ocorreram: a estrutura de uma das participantes desabou com o vento, fato que é bastante comum nas condições regionais. O plástico da cobertura, em uma das propriedades foi retirado pelo continuado "ressecamento do solo" nas condições do verão severo (em 2015), tendo em vista a insuficiente disponibilidade local de água. O cultivo protegido, na Comunidade Buriti, foi proposto para que os agricultores experimentassem e pudessem elevar a compreensão quanto à esse manejo do ambiente com hortaliças, tendo em vista que, para eles, o período chuvoso é a melhor época de cultivo, em face dos problemas relacionados com a disponibilidade de água. Todos ficaram cientes de que o cultivo protegido pode ser utilizado em qualquer época, entretanto, no período não-chuvoso se pode recorrer à forma não-protegida. É pertinente comentar que, um fator limitante para que o agricultor adote uma tecnologia é a disponibilidade de crédito e, na agricultura familiar, não é comum o investimento com recursos próprios. Convém lembrar que "a baixa capacidade financeira da unidade agrícola implica na baixa aquisição de tecnologia” (Mendes, 2015).

A irrigação por gotejamento em geral está associada ao cultivo protegido. Contudo, mostrou-se dispendiosa para os integrantes. Porém, a questão mais limitante se relacionou com a "falta de água" na Comunidade, que não possui infraestrutura de captação seja de igarapé ou de poço. No local da UO, a captação era feita de um igarapé próximo, por meio de bomba a combustível, que ocasionava gastos regulares com o produto. Segundo Mendes (2015), no topo da pirâmide da transferência estão como usuários os grandes produtores que também são inovadores, enquanto na base estão os pequenos produtores, que, limitadamente em algumas situações têm capacidade de subsidiar uma inovação incremental”. O local da UO foi escolhido consensualmente justamente pela disponibilidade de água, por captação do igarapé. A água para irrigação das hortaliças é limitante, pois são culturas exigentes nesse componente do sistema de cultivo. Segundo os integrantes do grupo, a situação poderá ter sensível melhoria, caso o INCRA construa o poço prometido para a Comunidade. Tal problema persiste desde a conversão produtiva, ocorrida anteriormente.

De modo geral, os integrantes conduzem o cultivo protegido com irrigação por meio da irrigação manual, com irrigadores, que de certa forma caracteriza uma adequação às suas inexistentes condições de investimentos. 
Manejo do solo - Todos os integrantes estão fazendo uso de calcário dolomítico, fosfato natural, esterco de galinha, composto orgânico e biofertilizante enriquecido, conforme o manejo na UO. Mas, ressalvaram que a obtenção do esterco bovino (para uso no biofertilizante) é mais complicado que a obtenção do esterco de galinha. Embora haja fonte de esterco bovino bem próximo, entretanto, eles enfrentam dificuldades de transporte o que limita a sua obtenção. Somente uma das mulheres possui um boi, que fornece o esterco que a mesma utiliza, além de doar também. É fundamental, no manejo orgânico, a integração da agricultura e da pecuária para fertilização do solo (Mazzoleni \& Nogueira, 2006). Esse aspecto fora anteriormente tratado, entretanto, o esterco bovino é o resíduo mais comum usado no preparo de biofertilizante, proporcionando um bom exemplo para uso de outros resíduos na preparação desse insumo. Alves et al. (2006) afirma que o agricultor familiar escolhe a tecnologia considerando as restrições das quais não pode se evadir. Portanto, aqui, o transporte foi a restrição incontornável, momentânea. Assim, o biofertilizante vem sendo fabricado com outros resíduos.

Espécies cultivadas - a diversificação das espécies é continuamente alterada, orientada pela procura e influenciada pela decisão de cada participante. Assim, as culturas de fácil comercialização (coentro, cebolinha, pimenta-de-cheiro, pimenta malagueta, salsinha e alface) é mais frequente entre todos, enquanto outras aparecem nos cultivos por alguns (tomate, pepino, berinjela, maxixe, rúcula, couve-de-folhas, alface americana, beldroega e brócolis). Convém destacar que a alface americana, o brócolis e a rúcula vem assumindo destaque na Comunidade. $\mathrm{Na}$ propagação das espécies, prioritariamente, estão adotando a semeadura em bandejas, conforme demonstrado na UO.

\section{Conclusões}

Concluiu-se que a UCM constituiu-se numa referência eficaz em termos de transferência de tecnologia, em face da adoção das práticas relacionadas com os cultivos em si, portanto, atestando sua reprodução. As práticas de manejo orgânico do solo e de uso de biofertilizante estão incorporadas nos modestos sistemas de cultivo dos integrantes. Os entraves observados devem-se a que as tecnologias de maiores capacidades de resposta exigem investimentos, desse modo, a falta de capacidade financeira restringe a opção dos agricultores familiares, por exemplo, a produção protegida associada com a irrigação por gotejamento. A irrigação por gotejamento não foi absorvida pelos integrantes, com a produção protegida funcionando com 
irrigação manual, ainda que o gotejo seja uma tecnologia amplamente adotada por parcela de agricultores familiares nas condições regionais, sendo reconhecida pela economia de água e de mão-de-obra. Portanto, configurou-se adaptação para adequação às circunstâncias socioeconômicas dos integrantes. No cômputo geral, concluiu-se que a validação tecnológica se deu, com aspectos que se modificaram circunstancialmente, sem dissociação das características dos recursos tecnológicos empregados. Isso porque, segundo Dereti (2009), validação tecnológica é o processo metódico e controlado de determinação da indissociabilidade de características da tecnologia, sob diferentes circunstâncias de aplicação, assim permitindo a reprodutibilidade dos efeitos de sua aplicação e assegurando sua confiabilidade, contudo, os aspectos que se modificam circunstancialmente, tornando-a adaptável e versátil devem ser resguardados”.

\section{Registro de Visita Técnica}

$\mathrm{Na}$ fase de condução, logo após a implantação das culturas, a UCM recebeu a visita do Comitê Técnico Científico da Embrapa Amazônia Ocidental (Figura 10), tendo ocorrido expressivos depoimentos sobre a experiência em curso, com ênfase ao aprendizado obtido e a importância desse tipo de trabalho para a melhoria da qualidade de vida das famílias participantes.

\section{Referências}

ALVES, E.; MONTOVANI, E.C.; OLIVEIRA, A.J. Benefícios da mecanização da agricultura. In: ALVES, E. (Ed) Migração rural-urbana, agricultura familiar e novas tecnologias: coletânea de artigos revistos. Brasília: Embrapa Informação Tecnológica, 2006. p. 143 - 150. AMARO, G.B; SILVA, D.M. da; MARINHO, A.G; NASCIMENTO, W.M. Recomendações técnicas para o cultivo de hortaliças em agricultura familiar. Brasília: Embrapa Hortaliças 2007. 16 p. (Embrapa Hortaliças Circular Técnica, 47).

CAMPANHOLA, C.; VALARINI, P.J. Agricultura orgânica e seu potencial para o pequeno agricultor. Cadernos de Ciência e Tecnologia, Brasília, v. 28, n.3, p. 69-101, 2001.

CARDOSO, M.; BERNI, R.F. Nitrogen applied in okra under non-tightness grown and residual fertilization. Horticultura Brasileira, v. 30, n.4, p. 645 - 652, 2012. 
CASTRO NETO, N. de; DANUZZI, V.S.S; RINALDI, R.N; STADUTO, J.A.R. Produção orgânica: uma potencialidade estratégica para agricultura familiar. Revista Percurso-NEMO, Maringá, v. 2, n. 2, p. 73-95, 2010.

COSTA, J.R. da; SOARES, J.E.C. Projeto Tarumã Vida. In: FERRARO JUNIOR, L. A. (Org.). Encontros e Caminhos: Formação de Educadoras(es) Ambientais e Coletivos Educadores - Volume 3. Brasília: MMA/DEA, 2013. 452 p. p. 323 - 334.

DERETI, R.M. Transferência e validação de tecnologias agropecuárias a partir de instituições de pesquisa. Desenvolvimento e Meio Ambiente, n.19, p. 29-40, 2009. Disponível em: http://www.alice.cnptia.embrapa.br/bitstream/doc/580071/1/Transferenciaevalidacaodetecnol ogiasagropecuarias....pdf Acesso em 08 de março de 2016.

IBGE. Instituto Brasileiro de Geografia e Estatística. Pesquisa de orçamentos familiares POF 2002-2003. Rio de Janeiro: IBGE, 2011. Disponível em: http://www.ibge.gov.br/home/presidencia/noticias/noticia_visualiza.php?id_noticia=278 Acesso em 26 de agosto de 2011.

EMATER. Agência Goiana de Assistência Técnica, Extensão Rural e Pesquisa Agropecuária (Ed). Metodologia de Extensão Rural: supervisão de metodologia e capacitação. Goiânia: EMATER, 2009. 104 p. Disponível em: http://www.emater.go.gov.br/intra/wpcontent/uploads/downloads/2012/10/Apostila-Metodologia-Ext.Rural_.pdf Acesso em 05 de fevereiro de 2016.

EMBRAPA. Empresa Brasileira de Pesquisa Agropecuária / Secretaria de Gestão e Estratégia - SGE / Coordenadoria de Avaliação de Desempenho Institucional -CADI. Manual dos indicadores de avaliação de desempenho dos centros de pesquisa da Embrapa - Período 2008/11. Brasília: Embrapa, 2009. Disponível em: http://www.cpac.embrapa.br/publico/usuarios/uploads/P\&D/NAP/manual_indicadores_sau_ul tima\%20versao.pdf Acesso em 05 de fevereiro de 2016.

FRANCO, C.F. de O. Dinâmica da transferência de tecnologia no sistema produtivo da agricultura brasileira. In: II Simpósio Nacional sobre as culturas do inhame e do taro. João Pessoa, PB. Anais... João Pessoa-PB: Emepa-PB, 2002. V. 2, 224 p. 
GUANZIROLI, C. et al.: Agricultura Familiar e Reforma Agrária no Século XXI. Rio de Janeiro: Garamond, 2001. 288p.

INCRA - Instituto Nacional de Colonização e Reforma Agrária. Diagnóstico SócioEconômico-Ambiental do Projeto de Assentamento Tarumã Mirim. Manaus, 1999.

MATOS, L.L.de; PEIXOTO, R.A; COSTA, R.C. Os assentados e a cidade: o assentamento Tarumã-Mirim e Manaus (AM). XIX Encontro Nacional de Geografia Agrária, São Paulo, 2009 , p. 1-9.

MAZZOLENI, E. M; NOGUEIRA, J. M. Agricultura orgânica: características básicas do seu produtor. Rev. Econ. Sociol. Rural [online]. 2006, vol.44, n.2, pp. 263-293. ISSN 1806-9479. Disponível em: http://dx.doi.org/10.1590/S0103-20032006000200006 Acesso em 15 de fevereiro de 2016.

MELO, W.F. de. Inovação tecnológica na agricultura: condicionantes da dinâmica da tecnologia "alho-semente livres de vírus" nas regiões de Cristópolis e Boninal, na Bahia. Brasília: Centro de Desenvolvimento Sustentável - Universidade de Brasília, 2008. 103 p. (Dissertação de Mestrado).

MENDES, C.I.C. Transferência de tecnologia: rumo à inovação. Campinas: UNICAMP, 2015. 386f. (Tese Doutoramento).

NASCIMENTO, J. L. A. do. Uso de geotecnologia no monitoramento de unidades de conservação: Ocupações peri-urbanas na Apa margem esquerda do Rio Negro. Manaus: Universidade Federal do Amazonas, 2010. 117p. Dissertação de Mestrado em Ciências do Ambiente.

NASCIMENTO, J.L.A, do; SILVA, N.M. da. Uso de geotecnologias no monitoramento de unidades de conservação: ocupações peri-urbanas na APA Margem Esquerda do Rio Negro Manaus. Anais do I Seminário Internacional de Ciências do Ambiente e Sustentabilidade da Amazônia. $\quad$ p. $1-8$. Disponível http://seminariodoambiente.ufam.edu.br/2010/anais/rn64.pdf Acesso em 11 de fevereiro de 2016.

NODA, S. do N.; NASCIMENTO, E.A do; LOURENÇO, F. de S.; MENDONÇA, M.S.P.; COSTA, O.L.; KAWAKAMI, C.Y. Pesquisa-ação para construção do conhecimento 
agroecológico em sistema de produção familiar na Comunidade Boa Esperança Itacoatiara/AM. Rev. Bras. De Agroecologia, v.4, n.2, p.3803 - 3806, 2009.

OLIVEIRA, F. das C; SOUSA, V.F.de; OLIVEIRA JUNIOR, J.O.L. de (Eds). Estratégias de desenvolvimento rural e alternativas tecnológicas para a agricultura familiar na Região Meio-Norte. Terezina: Embrapa Meio-Norte, 2008. 376 p. 


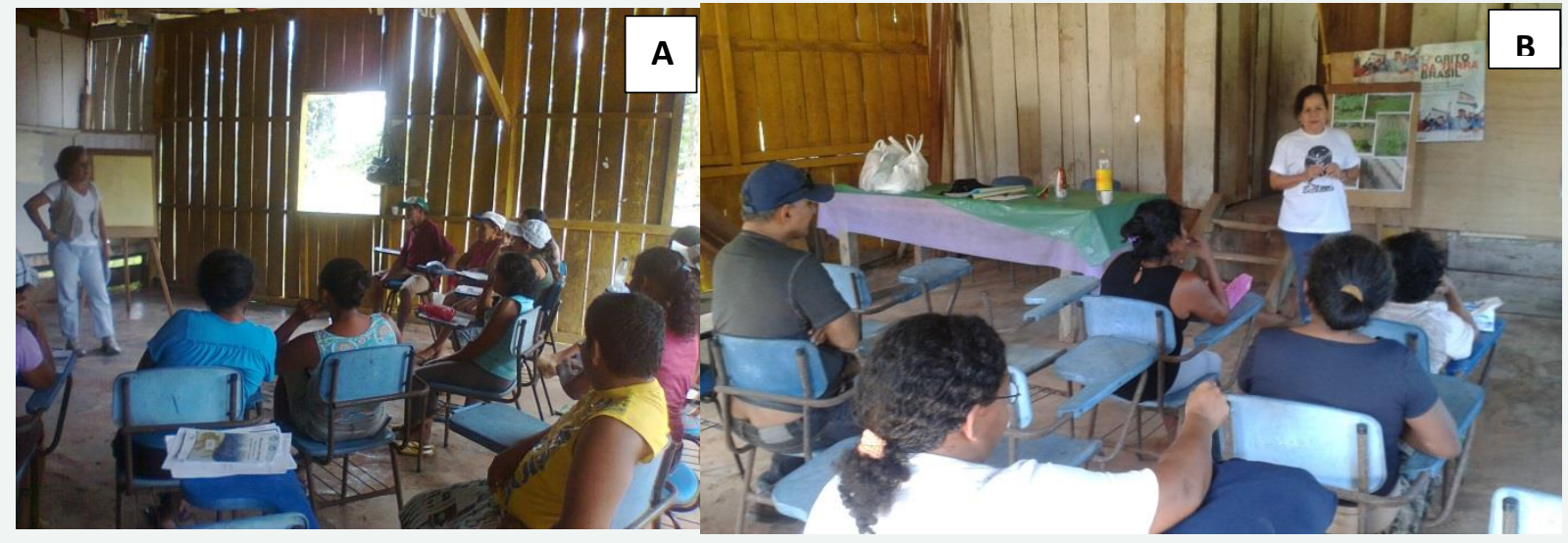

Fotos: Joanne R. da Costa

Figura 1. Palestra preliminar (a) e de apresentação do projeto base das ações (b). Manaus, Embrapa Amazônia Ocidental, 2014.

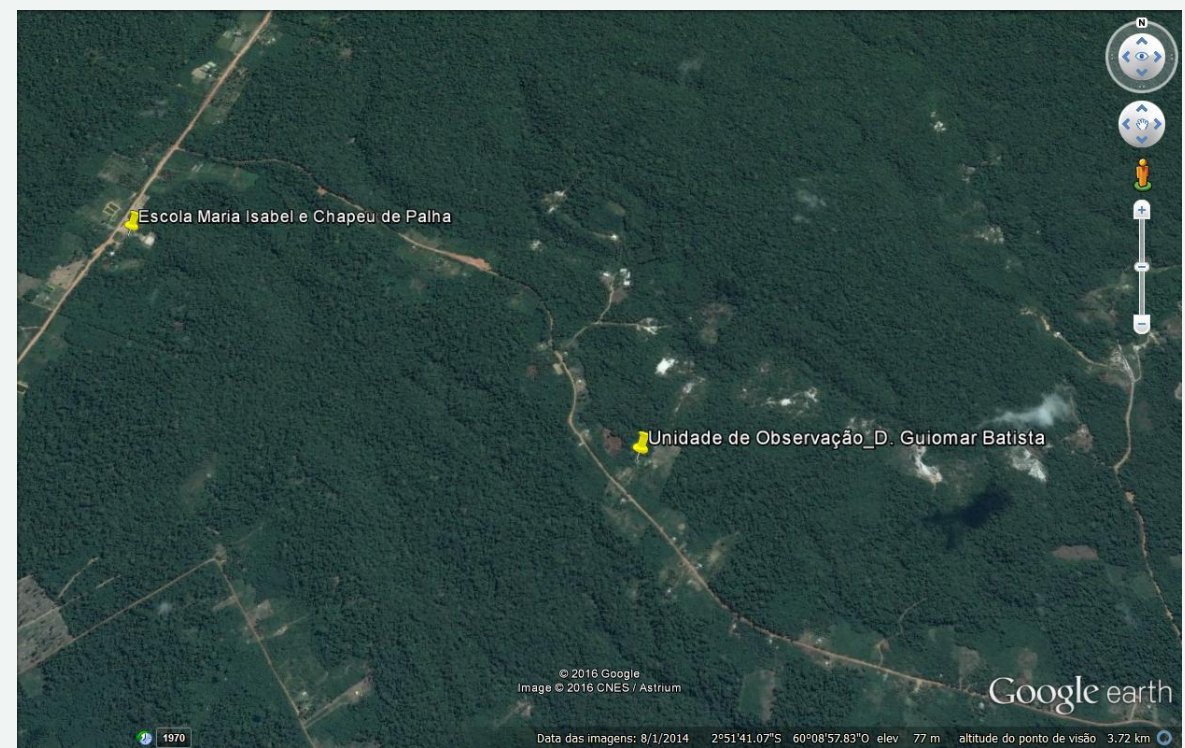

Foto: Adaptação Gilvan C. Martins

Figura 2. Local da Unidade Central Modelo/Unidade de Observação na Comunidade Buriti. Manaus, Embrapa Amazônia Ocidental, 2014. 

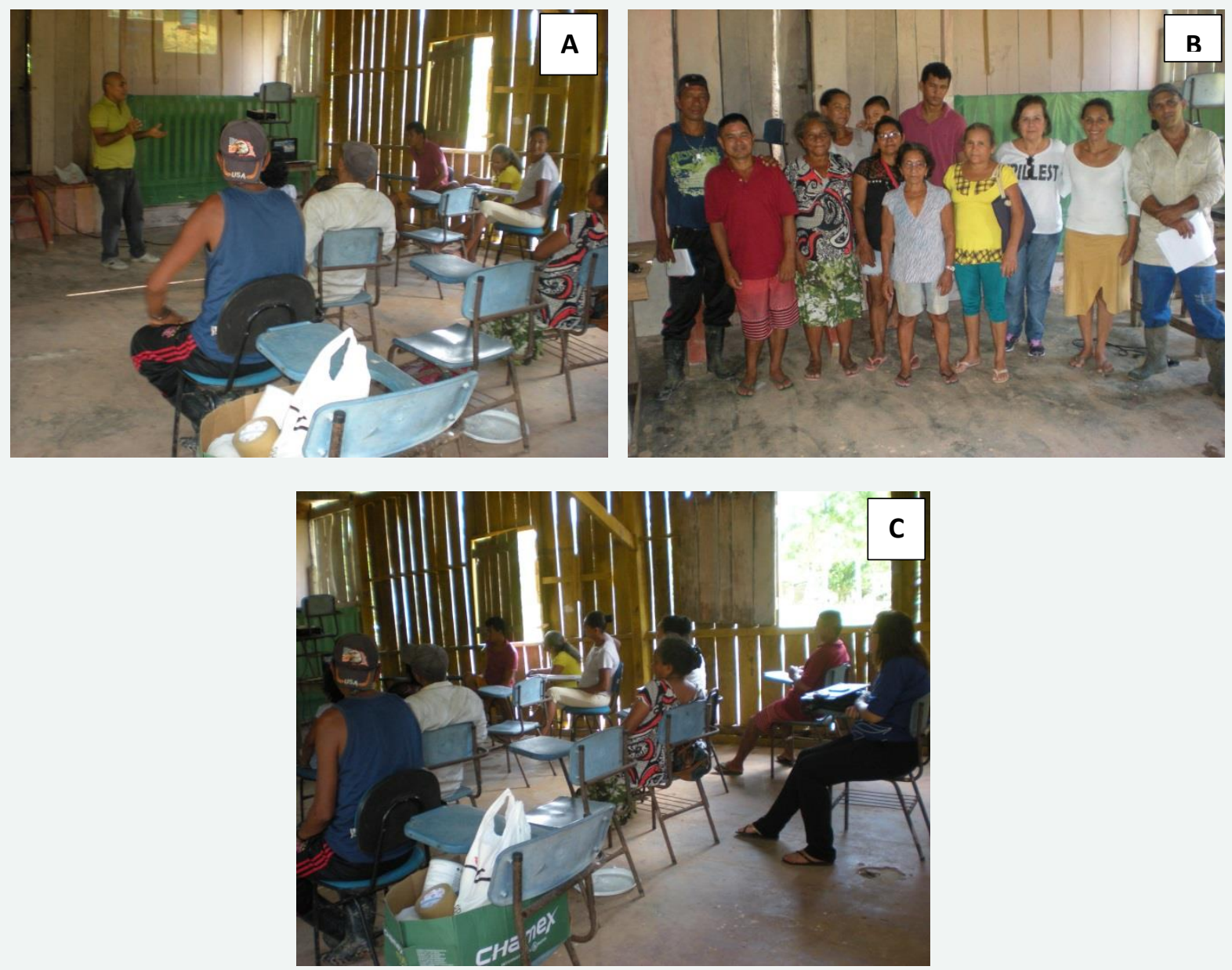

Fotos: Joanne R. da Costa (B); Marinice O. Cardoso (A e C)

Figura 3. Aspectos do curso "Temas e práticas sobre agricultura orgânica adaptadas às condições da Comunidade Buriti - Tarumã Mirim”. Manaus, Embrapa Amazônia Ocidental, 2014. 

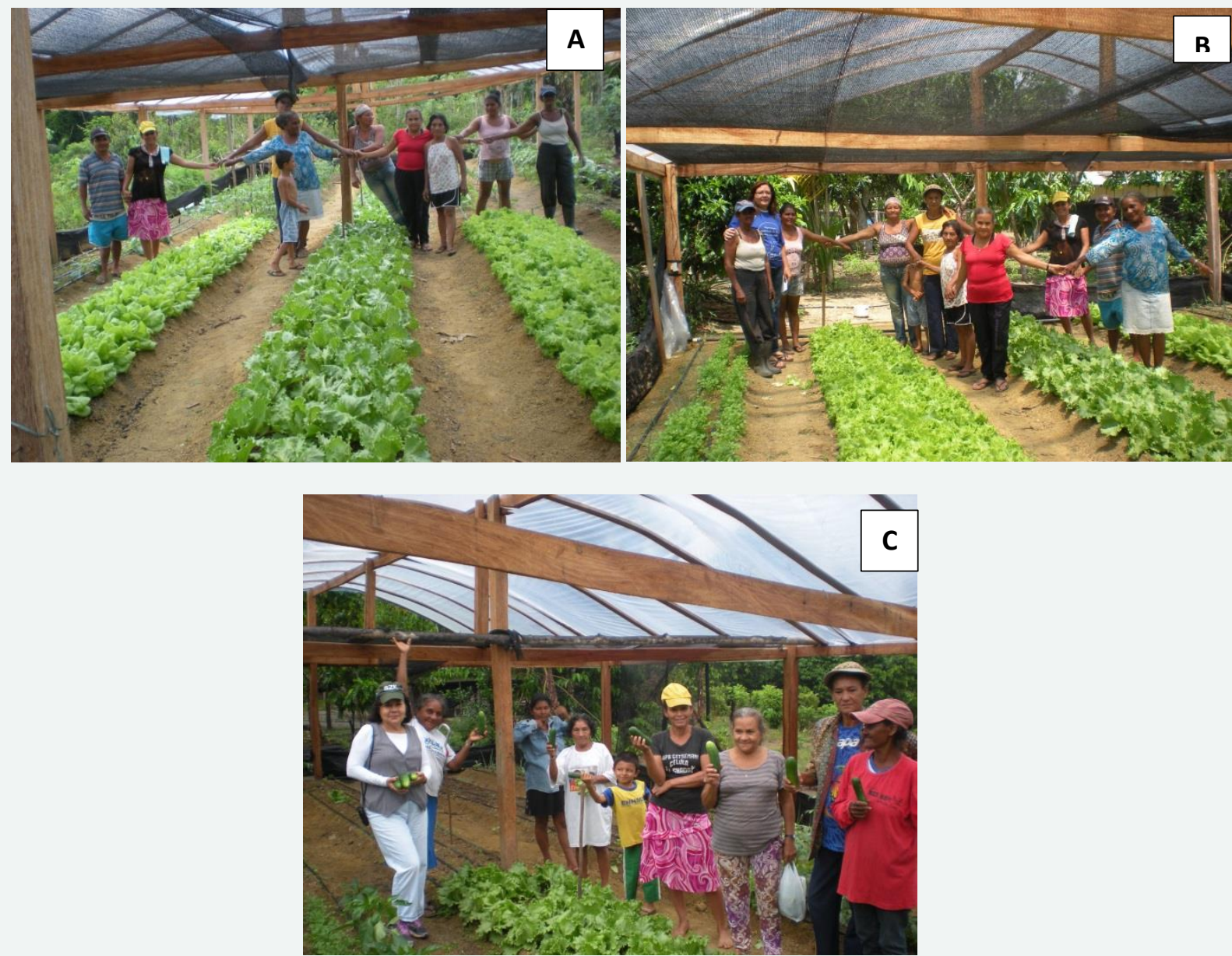

Fotos: Joanne R. da Costa (C); Marinice O. Cardoso (A e B)

Figura 4. Os participantes próximo à colheita das hortaliças na Unidade de Observação (a e b), com destacada participação das mulheres; na colheita de pepino (c). Manaus, Embrapa Amazônia Ocidental, 2014.

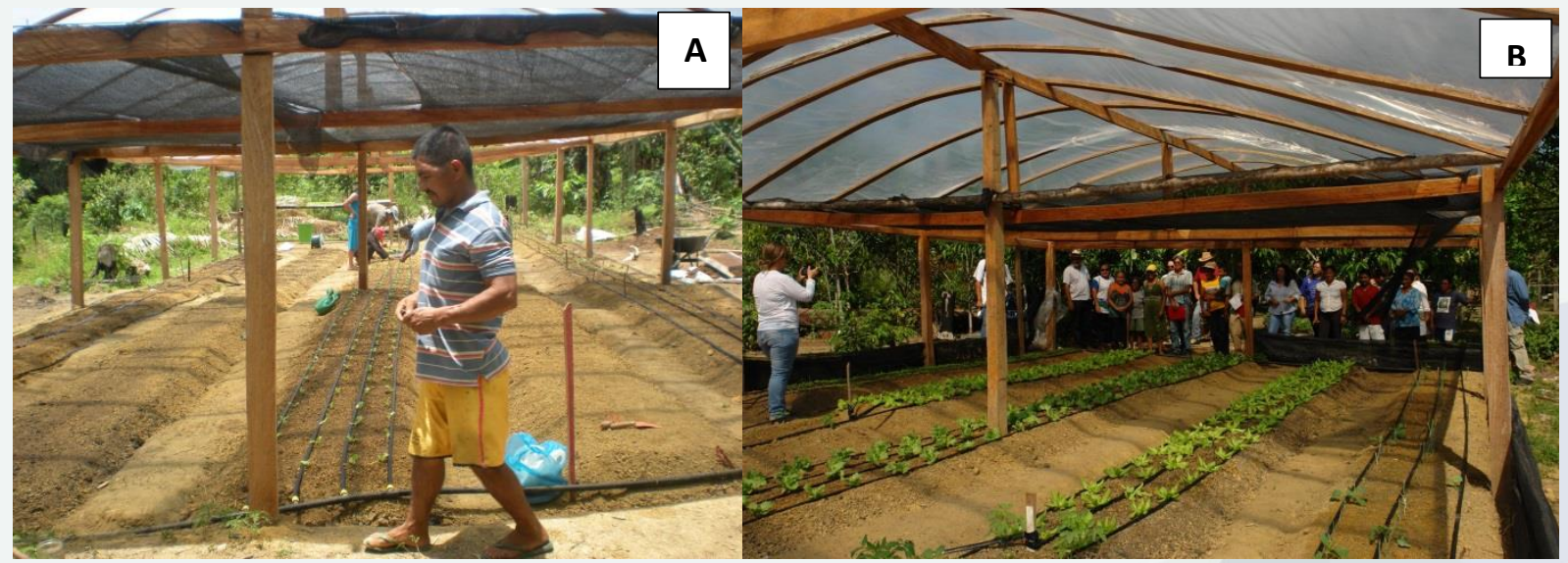

Fotos: Joanne R. da Costa (B); Marinice O. Cardoso (A)

Figura 5. Aspectos da estrutura de cultivo protegido, com sombrite em sua metade. Manaus, Embrapa Amazônia Ocidental, 2014. 

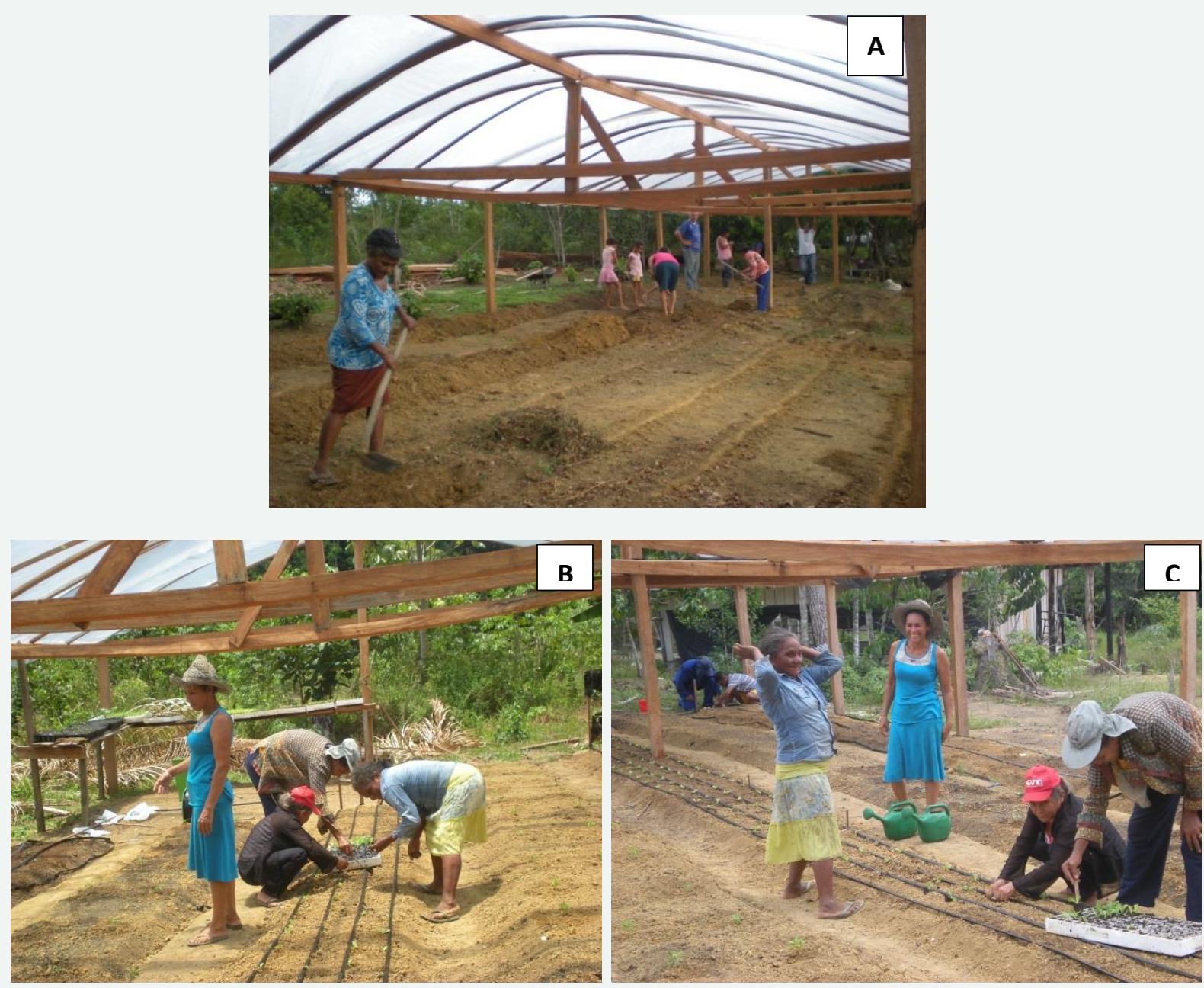

Fotos: Marinice O. Cardoso

Figura 6. Confecção dos canteiros (a), semeadura em bandejas (b) e transplantio de mudas (c) na Unidade de Observação. Manaus, Embrapa Amazônia Ocidental, 2014. 

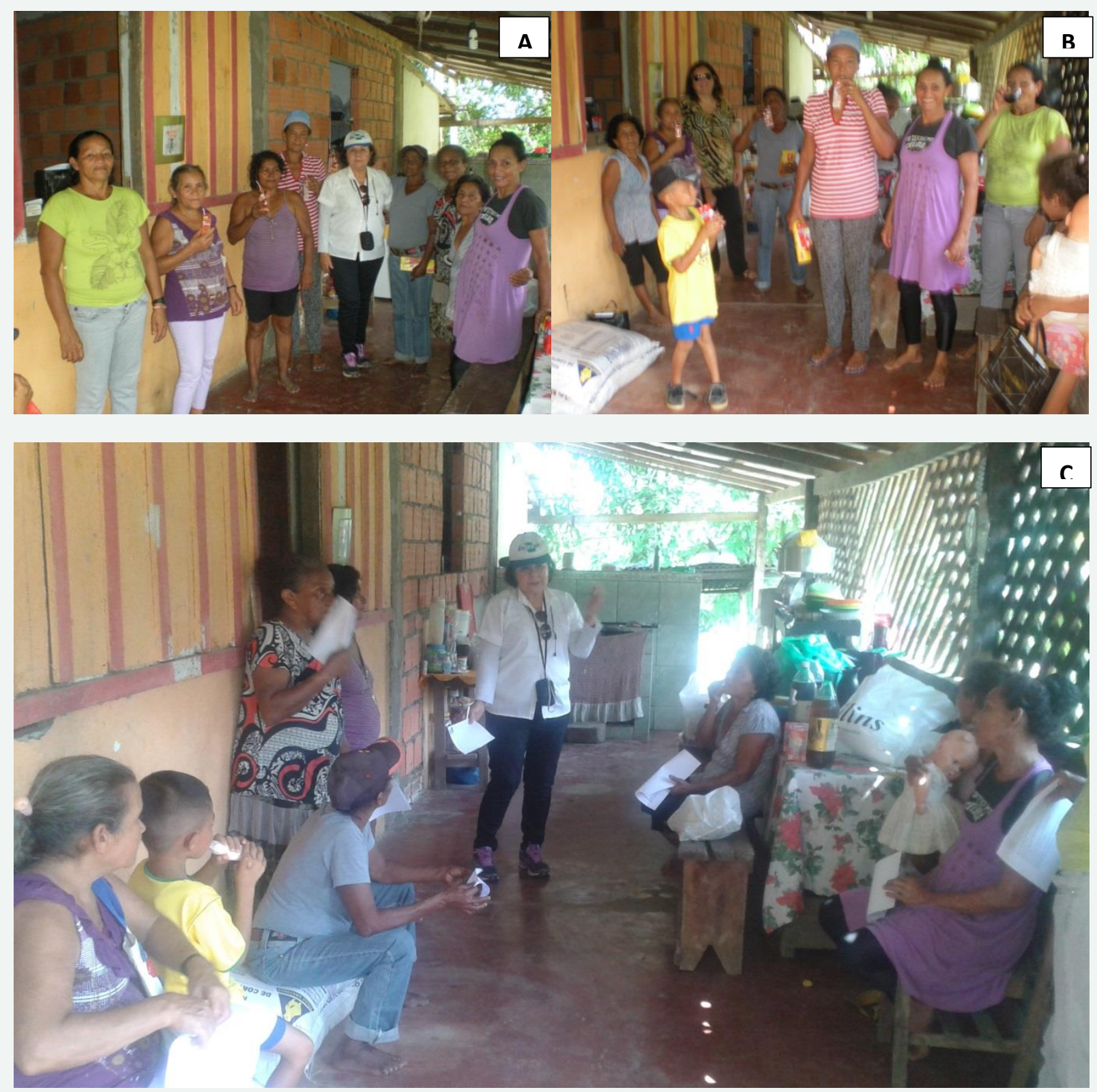

Fotos: Joanne R. da Costa (A e C); Marinice O. Cardoso (B)

Figura 7. Encerramento das atividades da Unidade de Observação e confraternização.

Manaus, Embrapa Amazônia Ocidental, 2014. 

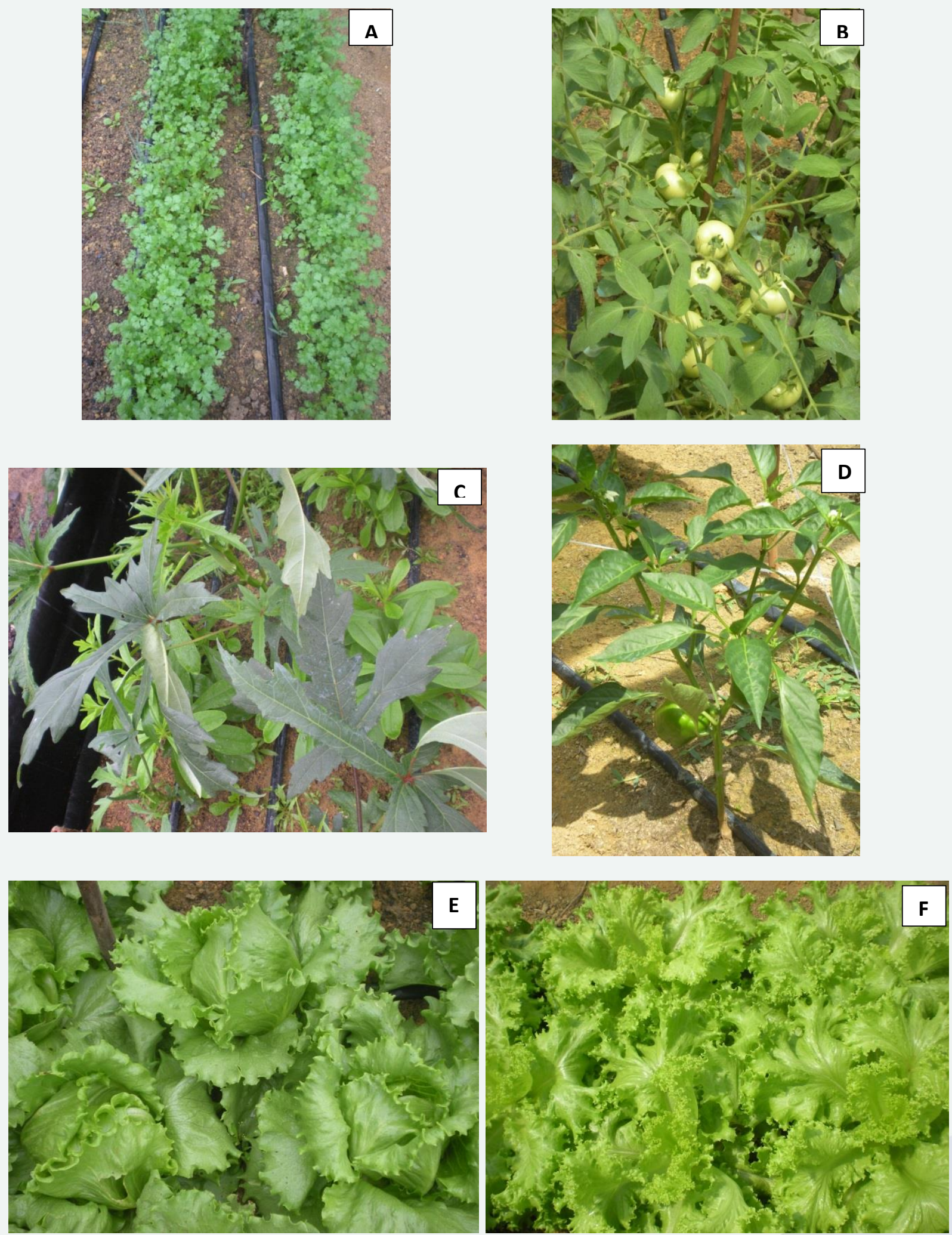

Fotos: Marinice O. Cardoso

Figura 8. Desempenho agronômico de algumas das diferentes espécies cultivadas na Unidade de Observação. Manaus, Embrapa Amazônia Ocidental, 2014. 

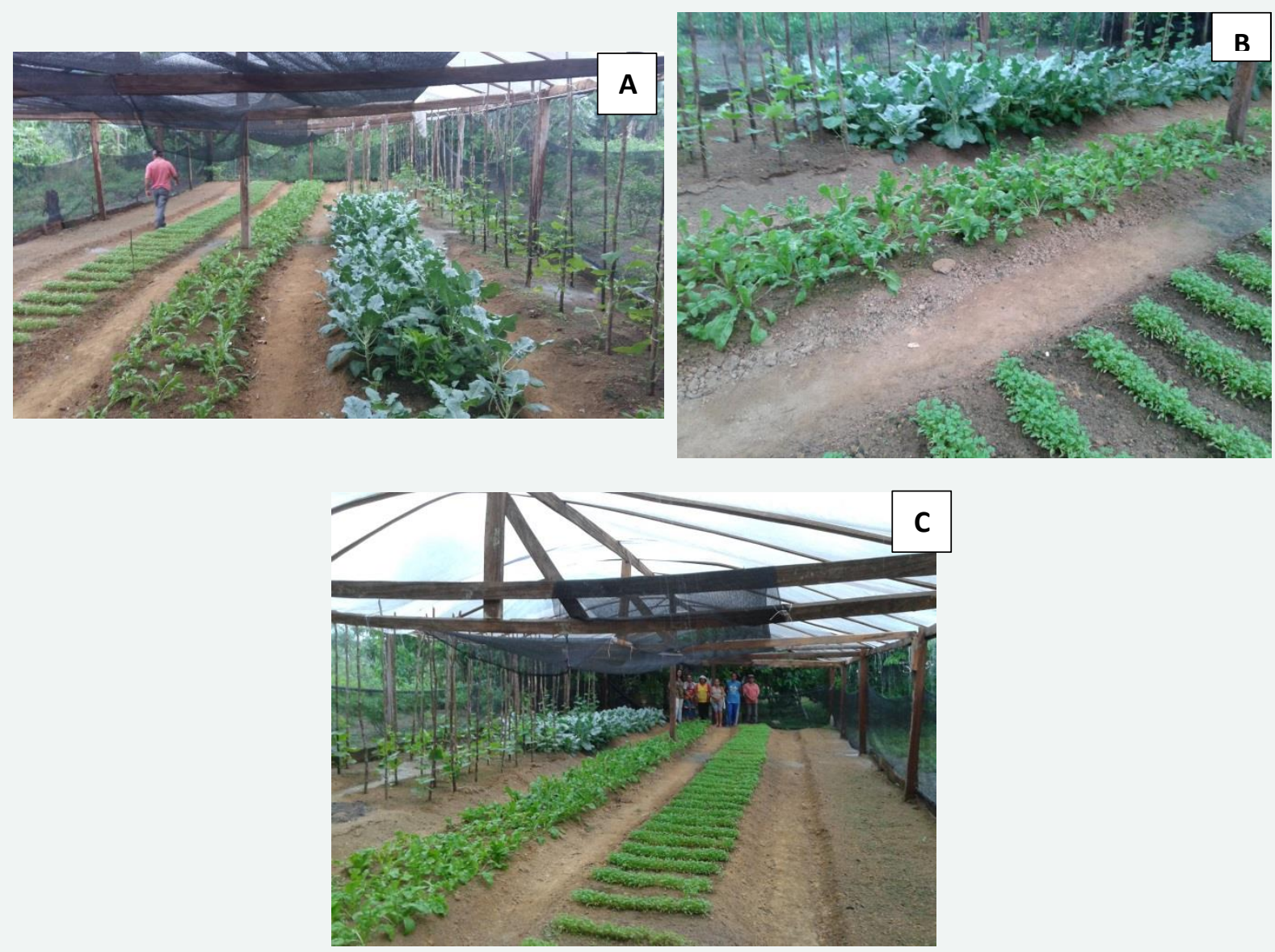

Fotos: Joanne R. Costa

Figura 9. A estrutura de cultivo protegido da Unidade de Observação continuou sendo utilizada pela família de D. Guiomar Batista, estando em março de 2016 ocupada com brócolis, rúcula, coentro e pepino. Manaus, Embrapa Amazônia Ocidental, 2014.
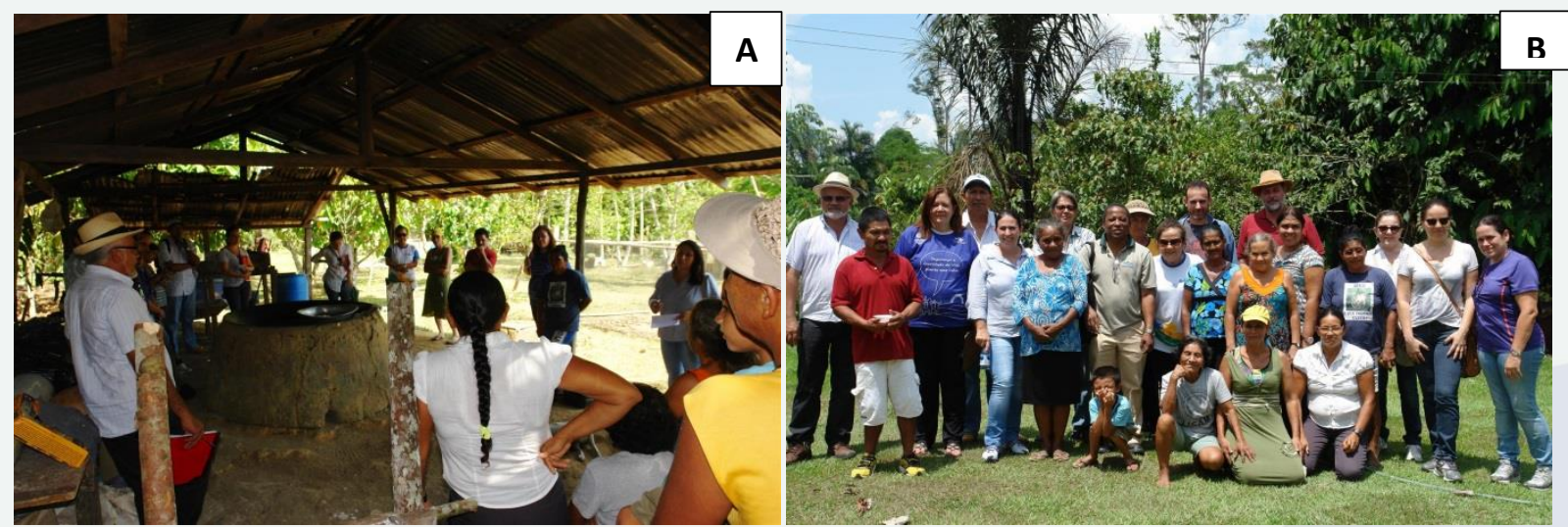

Fotos: Maria José Tupinambá

Figura 10. Por ocasião da visita do Comitê Técnico Científico da Embrapa Amazônia Ocidental à Unidade de Observação na Comunidade Buriti. Manaus, Embrapa Amazônia Ocidental, 2014. 